\title{
KEBIJAKAN PEMERINTAH DALAM MENGATASI KEMACETAN DI KOTA YOGYAKARTA (STUDI PENELITIAN DI JALAN MALIOBORO DAN JALAN TENTARA PELAJAR)
}

\author{
Siti Fatimah ${ }^{1}$, Syakdiah $^{2}$, Retno Kusumawiranti ${ }^{3}$ \\ 1,2,3Program Studi Administrasi Publik \\ Fakultas Ilmu Sosial dan Ilmu Politik Universitas Widya Mataram \\ Email: sitifatimah101298@gmail.com \\ syakdiah8@gmail.com \\ retno_zan@yahoo.co.id
}

\begin{abstract}
Abstraksi
Kemacetan biasa dijumpai di Kota Yogyakarta, disebabkan pertumbuhan kota yang juga diiringi pertambahan jumlah penduduk dan jumlah kendaraan, tapi tidak didukung infrastruktur yang bisa mengimbanginya. Dinas Perhubungan Kota Yogyakarta dan Polantas turun tangan untuk mengatasi kemacetan, beberapa kebijakan yang telah dilakukan, tapi belum bisa dikatakan baik karena masih ada beberapa masalah. Penelitian ini menggunakan metode kualitatif dengan pendekatan deskriptif. Penentuan informan, menggunakan teknik purposif sampling. Pengumpulan data digunakan teknik observasi, wawancara dan dokumentasi. Kebijakan pemerintah mengatasi kemacetan di Jalan Malioboro dan Tentara Pelajar seperti diadakannya rekayasa lalu lintas dimana ruas jalan tertentu dijadikan jalan satu arah atau pelebaran dan normalisasi simpang, pengembangan teknologi ATCS (Area Traffic Control System) dan pengalokasian disediakan lahan parkir pada ruas Jalan Malioboro dan Tentara Pelajar. Namum dalam pelaksanaannya masih banyak menghadapi hambatan dan kendala, menggunakan pendekatan teknologi membutuhkan anggaran besar dalam penyedian dan perawatannya dan kurangnya personil atau sumberdaya manusia untuk memproses pengaduan terhadap masalah yang terjadi dilapangan, dan kurangnya kesadaran masyarakat dalam menyukseskan programprogram.
\end{abstract}

Kata kunci : Kebijakan Pemerintah mengatasi kemacetan, rekayasa lalu lintas, teknologi ATCS (Area Traffic Control System), kesadaran masyarakat.

\begin{abstract}
Congestion is common in the city of Yogyakarta, due to the growth of the city which is also accompanied by an increase in population and the number of vehicles, but not supported by infrastructure that can compensate. Yogyakarta City Transportation Service and Polantas intervened to overcome traffic jams, several policies have been carried out, but it can't be said to be good because there are still some problems. This study uses a qualitative method with a descriptive approach. Determination of informants, using purposive sampling technique. Data collection used observation, interview, and documentation techniques. Government policies to overcome traffic jams on Malioboro street and the Tentara Pelajar street such as conducting traffic engineering where certain roads are used as one-way roads or widening and normalizing intersections, developing ATCS technology (Area Traffic Control System) and allocating available parking spaces on Malioboro and Tentara Pelajar street. However, in its implementation there are still many obstacles and hindrances, using a technological approach requires a large budget in the provision and maintenance, and a lack of personnel or human resources to process complaints against problems that occur in the field, and a lack of public awareness in the success of programs.
\end{abstract}

Keywords: Government policy to overcome congestion, traffic engineering, ATCS (Area Traffic Control System) technology, citizen's awareness

\section{Pendahuluan}


Pertumbuhan kota diiringi pertambahan jumlah penduduk dan jumlah kendaraan, di ruas-ruas jalan utama Kota Yogyakarta menyebabkan kemacetan terjadi setiap saat mulai dari pagi hingga malam hari. Pertumbuhan penduduk yang sangat tinggi, seperti banyaknya pelajar dan mahasiswa yang datang dari berbagai daerah di seluruh Indonesia. Juga terjadi akibat migrasi masyarakat dari luar daerah yang bekerja di wilayah DIY. Jalanan di DIY juga menjadi pintu perlintasan baik kendaraan dari Purworejo yang akan ke Solo, maupun kendaraan dari Magelang ke Jogja. Termasuk kendaraan wisatawan. Ini karena status DIY sebagai kawasan wisata sehingga berdampak pada meningkatnya volume kendaraan, pertumbuhan volume kendaraan bermotor di wilayah DIY juga tidak bisa dihindari. Setiap tahun, jumlah kendaraan baru terus bertambah. Di Kota Yogyakarta rata-rata setiap tahun ada penambahan mobil baru sekitar $4 \%$ dan sepeda motor baru sekitar 6\%. (jogjapolitan.harianjogja.com). Jumlah kendaraan bermotor saat ini di Yogyakarta sekitar 1,8 juta unit. Bertambahnya kendaraan bermotor belum diimbangi dengan penambahan ruas jalan baru. Kota Yogyakarta menjadi kota termacet ke-4 di Indonesia. (Sumber : https://joglosemarnews.com/ ).

Kemacetan lalu lintas telah menyebabkan 20\% dari bahan bakar yang digunakan oleh kendaraan roda empat hanya terbakar secara percuma karena mesin dalam keadaan menyala tanpa menghasilkan pergerakan. Dampak buruk lainnya pencemaran udara yang berasal dari gas buang kendaraan. Ada banyak titik rawan kemacetan yang terjadi di Yogyakarta, diantaranya Jalan Malioboro, Jalan P.Mangkubumi, Jalan P. Senopati, Jalan Kebon Raya, Jalan Tentara Pelajar, Jalan Timoho, Jalan Laksda Adisucipto, Jalan P. Diponegoro, Jalan Mataram, Jalan Magelang, Jalan A. Yani dan Jalan Brigjen Katasmo. Waktu macet biasanya terjadi sekitar pukul 07:00-08.00, 14.00-16.00, dan 16.30-20.00.

Jalan Malioboro merupakan pusat Kota Yogyakarta, pusat wisata dan ikon Kota Yogyakarta, sering terjadi kepadatan kendaraan sepanjang jalan Malioboro pada saat akhir pekan dan akan memuncak pada saat musim liburan. Jalan Tentara Pelajar merupakan jalan yang banyak terdapat beberapa sekolah maupun kantor dan instansi, saat jam-jam tertentu mengalami kepadatan kendaraan pada ruas jalan. Undang-undang Republik Indonesia Nomor 22 Tahun 2009 Tentang Lalu Lintas dan Angkutan Jalan.

"Kemacetan merupakan situasi atau keadaan tersendatnya atau bahkan terhentinya lalu lintas yang disebabkan oleh banyaknya jumlah kendaraan melebihi kapasitas jalan.” 
Menurut KBBI (Kamus Besar Bahasa Indonesia) definisi kemacetan ialah tidak dapat bekerja dengan baik, tersendat, serat, terhenti dan tidak lancar. Program-program yang telah dilakukan oleh pemerintah untuk mengurangi kemacetan di Kota Yogyakarta, yaitu:

a. Program peningkatan pengaturan lalu lintas dan angkutan.

b. Program pengendalian ketertiban dan kelancaran lalu lintas,

c. Program operasionalisasi dan optimalisasi penyelenggaraan perparkiran.

Program merupakan salah satu komponen dari kebijakan, Charles O Jones (dalam Tangkilisan, 2003), kebijakan terdiri dari komponen-komponen : Goal atau tujuan, plans atau proposal, program, decision atau keputusan dan efek. Dalam berbagai sistem politik, kebijakan publik diimplementasikan oleh badan-badan pemerintah. Badan-badan tersebut melaksanakan pekerjaan-pekerjaan pemerintah dari hari ke hari yang membawa dampak pada warga negaranya. (Subarsono, 2009). Kebijakan menurut pendapat Carl Friedrich yang dikutip oleh Wahab (Friedrich dalam Wahab, 2004) bahwa: “Kebijakan adalah suatu tindakan yang mengarah pada tujuan seseorang, kelompok atau pemerintah dalam lingkungan tertentu sehubungan dengan adanya hambatan-hambatan tertentu seraya mencari peluang-peluang untuk mencapai tujuan atau mewujudkan sasaran yang diinginkan".

Penelitian tentang kemacetan di kota Yogyakarta telah menjadi topik yang cukup menarik untuk di teliti. Hasil penelitian Yosept Tria N (2015) menyimpulkan pengendalian tempat dan tarif parkir (penertiban parkir) adalah kebijakan pembatasan lalu lintas yang terbaik untuk kota Yogyakarta. Pemerintah Kota Yogyakarta perlu melakukan langkah yang mengarah pada penggunaan kebijakan parkir sebagai metode pembatasan lalu lintas misal dengan : penertiban tempat / lokasi parkir dan peningkatan tarif parkir khususnya pada wilayah yang sering menyebabkan kemacetan karena hambatan samping. P. Jeschinta Junike Parintaningrum (2017) hasil penelitiannya, bahwa Dinas Perhubungan Kota Yogyakarta telah membuat kebijakan untuk mengatasi permasalahan kemacetan lalulintas dengan beberapa upaya, dengan disediakan marka jalan bagi jalur trans Jogja, pembuatan tempat parkir sepeda di samping halte trans Jogja, penyediaan halte portebel, penyediaan rambu-rambu lalulintas, dan ATCS (Area Traffic Control System). Kemacetan perlu diatasi, karena Menurut Santoso (1997), kerugian yang diderita akibat dari masalah kemacetan ini apabila dikuantifikasikan dalam satuan moneter sangatlah besar, yaitu kerugian karena waktu perjalanan menjadi panjang dan makin lama, biaya operasi kendaraan menjadi lebih besar dan polusi kendaraan yang dihasilkan makin bertambah. Pada kondisi macet kendaraan merangkak dengan kecepatan yang sangat rendah, pemakaian BBM menjadi sangat boros, mesin kendaraan menjadi lebih cepat arus dan buangan kendaraan yang dihasilkan lebih tinggi kandungan 
konsentrasinya. Pada kondisi kemacetan pengendara cenderung menjadi tidak sabar yang menjurus ke tindakan tidak disiplin yang pada akhirnya memperburuk kondisi kemacetan lebih lanjut lagi. Menurut Etty Soesilowati (2008), secara ekonomis, masalah kemacetan lalu lintas akan menciptakan biaya sosial, biaya operasional yang tinggi, hilangnya waktu, polusi udara, tingginya angka kecelakaan, bising, dan juga menimbulkan ketidaknyamanan bagi pejalan kaki. Menurut Tamin (2000:493), masalah lalu lintas atau kemacetan menimbulkan kerugian yang sangat besar bagi pemakai jalan, terutama dalam hal pemborosan waktu (tundaan), pemborosan bahan bakar, pemborosan tenaga dan rendahnya kenyamanan berlalu lintas serta meningkatnya polusi baik suara maupun polusi udara.

\section{METODE}

Metode penelitian yang digunakan metode deskriptif dengan pendekatan kualitatif. Penelitian deskriptif adalah suatu bentuk penelitian yang ditujukan untuk mendeskripsikan fenomena-fenomena yang ada, baik fenomena alamiah maupun fenomena buatan manusia" (Sukmadinata, 2006). Menurut Faisal (1992), metode penelitian deskriptif kualitatif upaya eksplorasi dan klasifikasi mengenai suatu fenomena atau kenyataan sosia, digunakan untuk memecahkan atau menjawab permasalahan yang sedang dihadapi pada situasi sekarang dengan tujuan utama untuk membuat penggambaran tentang sesuatu keadaan secara objektif dalam deskripsi situasi. Menurut (Sugiyono, 2009), metode penelitian kualitatif adalah metode penelitian yang berlandaskan pada filsafat postpositifsime, digunakan untuk meneliti pada kondisi objek yang alamiah (sebagai lawannya adalah eksperimen) dimana peneliti adalah sebagai instrument kunci, pengambilan sumber informan dan data dilakukan secara purposive dan snowbaal, teknik pengumpulan data dilakukan dengan triangulasi (gabungan) analisis data bersifat induktif / kualitatif, dan hasil penelitian kualitatif lebih menekankan pada makna daripada generalisasi. Penentuan informan didasarkan pada teknik purposive sampling. Menurut Sugiyono (2013) teknik pengumpulan data merupakan langkah yang paling strategis dalam penelitian, karena tujuan utama dari penelitian adalah mendapatkan data. Teknik yang digunakan observasi, wawancara dan dokumentasi. Menurut Miles \& Huberman (dalam Sugiyono, 2007) analisis terdiri dari tiga alur kegiatan yang terjadi secara bersamaan yaitu: reduksi data, penyajian data, penarikan kesimpulan / verifikasi.

\section{PEMBAHASAN}

Peningkatan pengaturan lalu lintas dan Angkutan Umum merupakan salah satu program dari Dinas Perhubungan Kota Yogyakarta. Program ini bertujuan untuk merekayasa 
lalu lintas, seperti merubah jalur jalan menjadi satu arah saja dan pelarangan yang diperuntukan untuk angkutan umum untuk melewati jalan-jalan yang kecil atau sempit. Salah satu upaya yang telah dilakukan oleh Dinas Perhubungan dalam menanggulangi kemacetan ini yaitu dengan membuat kebijakan program peningkatan pengaturan lalu lintas dan angkutan umum.

Jalan Malioboro termasuk ruas jalan yang padat pengunjung dan kendaraan. Jalan Malioboro selalu padat saat hari libur dan lumayan padat saat hari-hari biasa. Sedangkan Jalan Tentara Pelajar menjadi jalan yang terdapat dikelilingnya sekolah-sekolah dan juga kantor-kantor atau instansi pemerintahan, sehingga pada jam-jam tertentu Jalan Tentara Pelajar ini menjadi padat kendaraan dan kelancaran lalu lintasnya lumayan terganggu. Menanggapi hal tersebut, pihak Dinas Perhubungan Kota Yogyakarta juga telah melakukan beberapa upaya peningkatan pengaturan lalu lintas dan angkutan umum terhadap kepadatan yang terjadi pada ruas Jalan Malioboro dan Tentara Pelajar. Hasil wawancara dengan Bapak Agus Noto Sutrisno, ST, M.Sc, beliau menyampaikan beberapa hal :

"Jalan Malioboro ini mbak upayanya masih dijadikan jalan satu arah dan rekayasa lalu lintasnya pada jalan-jalan yang menuju ke Malioboro itu sendiri. Dan Jalan Malioboro ini mbak inshaallah tahun 2020 ini akan menjadi semi pedestrian sudah ada kesepakatan. Dari Dinas Perhubungan melakukan upaya untuk mengatasi kemacetan di Jalan Malioboro ini lebih ekstrim lagi mbak dengan manajemen lalu lintasnya yang kita ubah total. Jadi nanti kendaraan bermotor tidak boleh melewati Jalan Malioboro lagi hanya bus trans jogja, andong dan becak yang boleh melewati Jalan Malioboro, kalau untuk Jalan Tentara Pelajar itu untuk saat ini kita masih melakukan pengaturan lalu lintasnya seperti pelebaran dan normalisasi simpang yah seperti belok kiri jalan lurus itu mbak, tapi nanti Jalan Tentara Pelajar impian kita kedepan akan jadi satu arah semua mbak keselatan." ( Wawancara tanggal 19 Desember 2019)

Gambar 3.1.

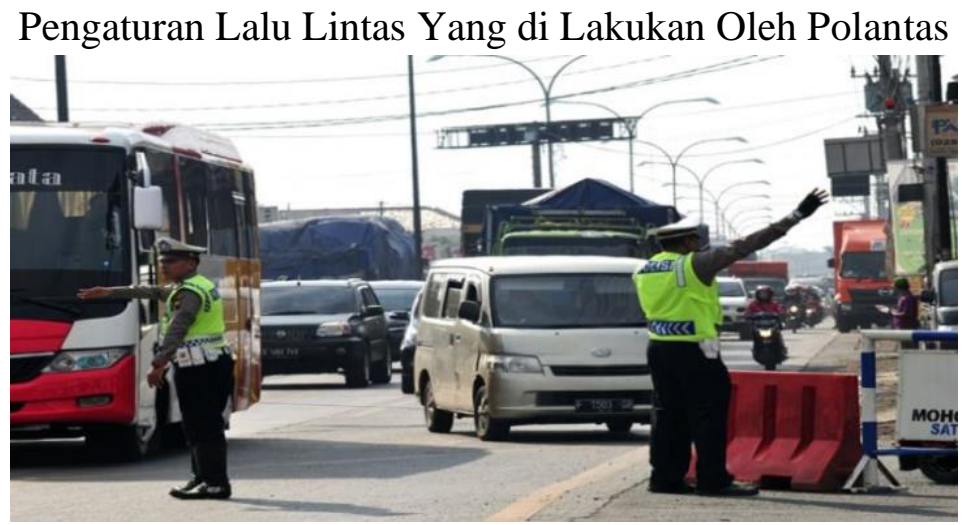

Sumber : Merahputih.com

Upaya dari Dinas Perhubungan Kota Yogyakarta dalam mengatasi kemacetan di Jalan Malioboro dengan program peningkatan pengaturan lalu lintas dan angkutan umum ini 
sudah cukup baik dalam pengaturan lalu lintas dan angkutan umum di Jalan Malioboro, namun masih harus terus dilakukan peningkatan-peningkatan dalam pengawasan pelaksanaan program tersebut dilapangan sehingga pada pelaksanaan program tersebut dapat berjalan dengan semestinya dan dapat mengurangi kemacetan yang terjadi di ruas Jalan Malioboro ini.

Gambar 3.2

Gambar Jalan Malioboro.

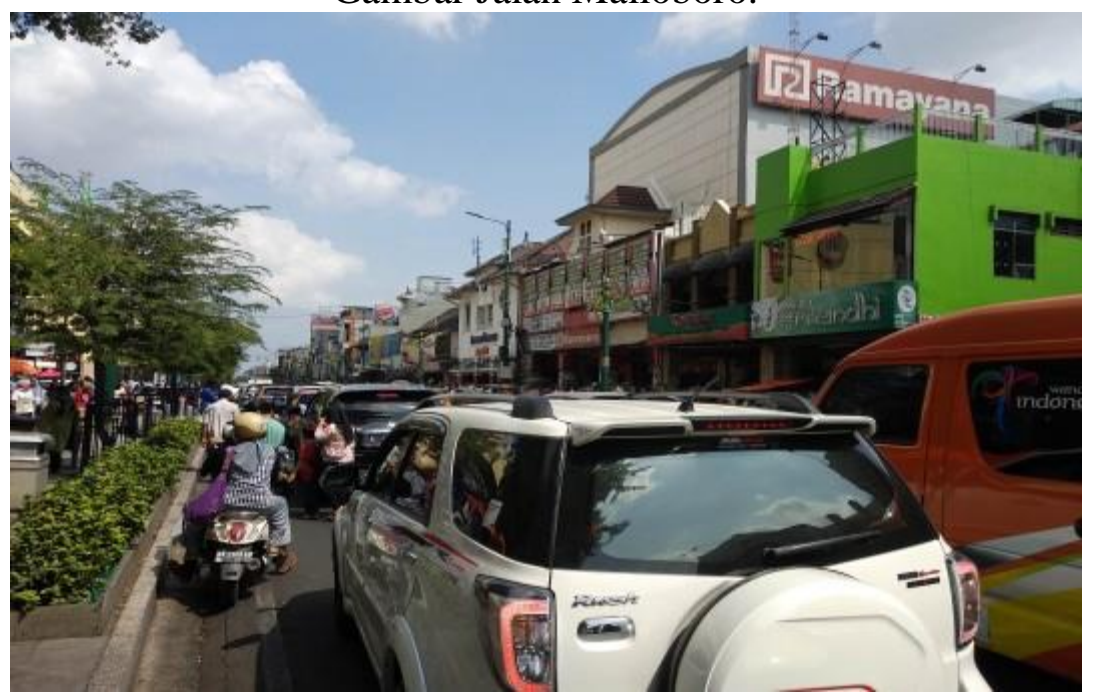

Sumber: Bernas.id

Gambar 3.3

Gambar Infrastruktur Manajemen Lalu Lintas Menuju Jalan Malioboro

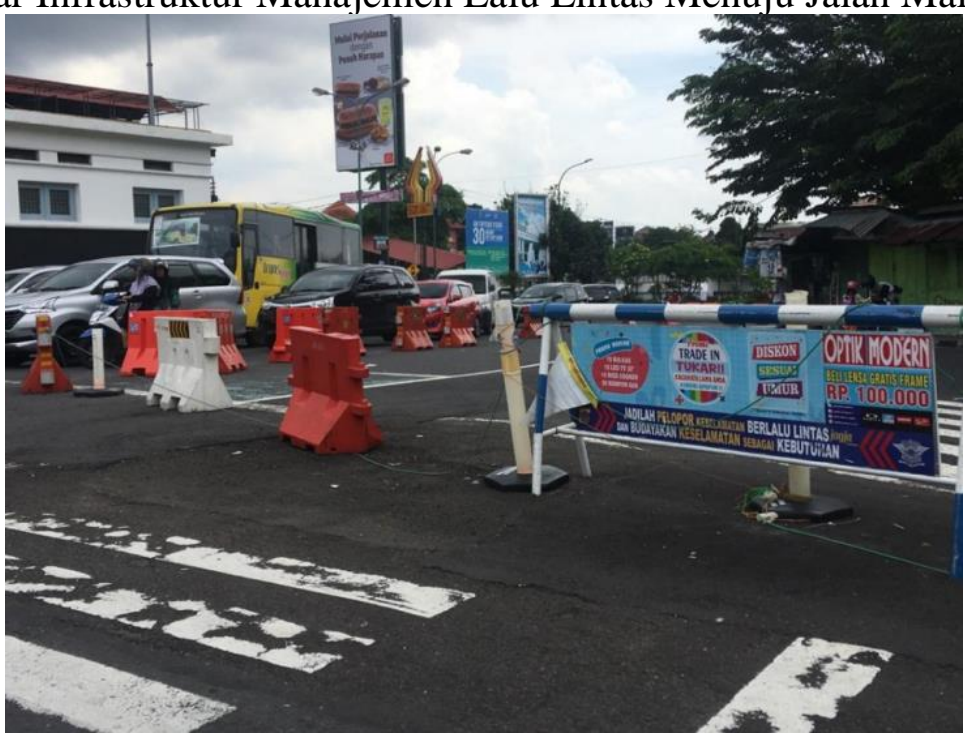

Sumber: Dokumentasi Peneliti 2020

Gambar 3.4 
Gambar Jalan Tentara Pelajar Pada Saat Padat Lalu Lintas

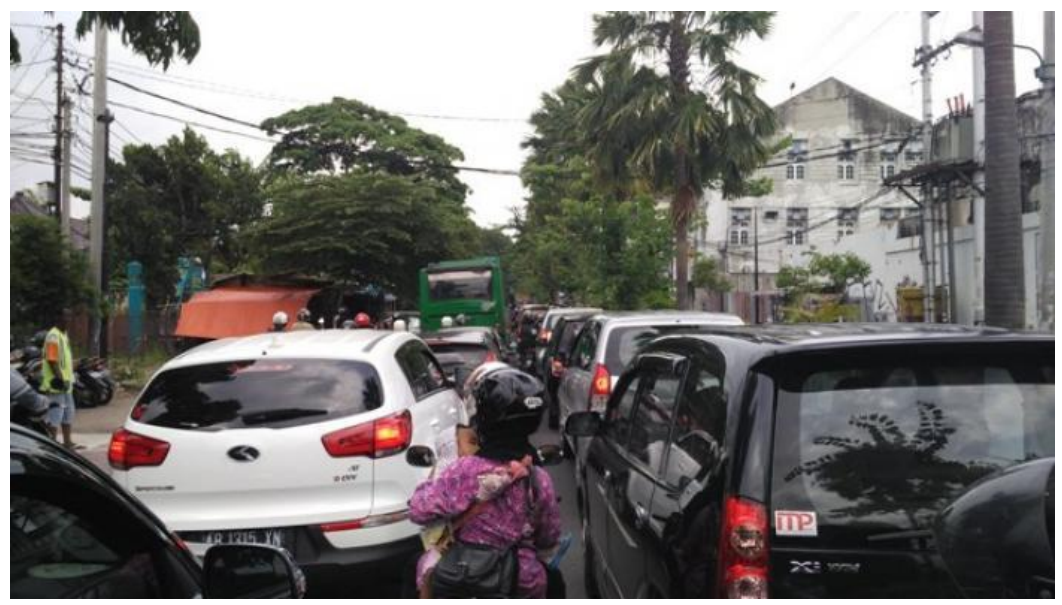

Sumber : Tribunnews.com

Upaya yang telah dilakukan dan dilaksanakan oleh Dinas Perhubungan Kota Yogyakarta yaitu program peningkatan pengaturan lalu lintas dan angkutan umum dalam menggurangi kemacetan di Jalan Tentara Pelajar ini dinilai cukup baik dan membantu pengguna jalan dengan pengaturan lalu lintasnya, seperti adanya belok kiri jalan lurus sehingga dapat menggurangi kemacetan lalu lintas yang panjang karena menunggu pergantian lampu merah yang terbilang cukup lama pada simpang Jalan Tentara Pelajar tersebut. Program pengendalian ketertiban dan kelancaran lalu lintas ini merupakan salah satu dari tiga program utama Dinas Perhubungan Kota Yogyakarta dalam mangatasi kemacetan yang terjadi di Kota Yogyakarta. Program pengendalian ketertiban dan kelancaran lalu lintas ini bertujuan untuk meningkatkan ketertiban terhadap pengendara lalu lintas untuk menaati peraturan berlalu lintas, seperti melanggar lampu merah dan melawan arus jalan yang dapat menganggu kelancaran lalu lintas.

Berdasarkan hasil observasi peneliti di lapangan masih banyak pengendara yang melanggar peraturan-peraturan lalu lintas, seringkali perilaku pengendara yang melanggar itu menjadi sebab terganggunya kelancaran lalu lintas dan merugikan bagi pengendara lainnya. Hal serupa juga disampaikan oleh beberapa pengguna jalan yang diwawancarai oleh peneliti di lapangan bahwasannya kemacetan juga terjadi bukan hanya karena volume pengendara yang banyak saja akan tetapi juga terjadi karena adanya pengendara lain yang tidak mentaati peraturan-peraturan yang ada seperti adanya pengendara yang stop dipinggir jalan padahal dilokasi tersebut dilarang berhenti sehingga menganggu pengendara yang ada dibelakangnya. Dokumentasi pelaksanaan program pengendalian ketertiban dan kelancaran lalu lintas seperti sarana dan prasarana. 
Gambar 3.5

Gambar Fasilitas dan Sarana Prasarana dari ATCS

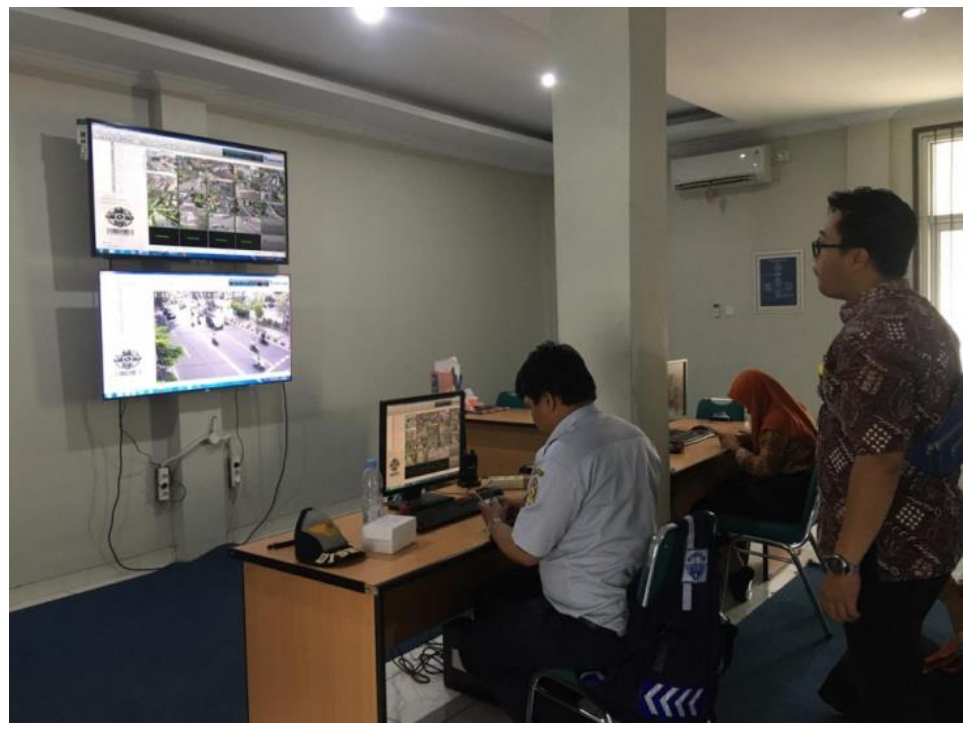

Sumber : Dokumentasi Peneliti 2019

Gambar diatas merupakan ruangan pusat kontrol dari teknologi ATCS ini disana para pegawai yang bertugas akan melakukan pengawasan dan pengendalian terhadap simpang-simpang yang telah terpasang teknologi ATCS, jika ada simpang yang terlihat mengalami kepadatan kendaraan saat menunggu lampu merah maka para pegawai yang bertugas akan mempercepat waktu merahnya sehingga pada sisi simpang yang mengalami kepadatan kendaraan itu akan berkurang dengan cepat dan tidak menganggu kelancaran lalu lintas di simpang tersebut.

Gambar 3.6

Gambar Data Simpang Kota Yogyakarta.

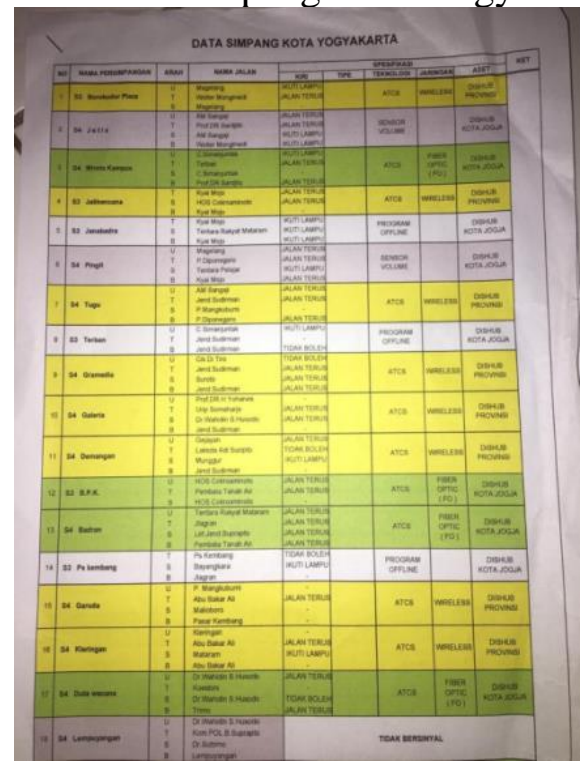

Sumber : Dokumentasi Peneliti 2019 
Simpang-simpang di Kota Yogyakarta yang saat ini sudah ada 30 simpang yang terdata telah menggunakan teknologi ATCS ini, dan sisa simpang lainnya tercatat masih menggunakan teknologi sensor volume, jaringan wireless dan fiber optic. Pada simpang Jalan Malioboro sudah dipergunakan teknologi ATCS ini jadi pengendalian ketertiban dan kelancaran lalu lintasnya di kendalikan dari kantor Dinas Perhubugan Kota Yogyakarta, sedangkan pada simpang Jalan Tentara Pelajar masih terdata mengunakan teknologi sensor volume dimana sensor volume tersebut berfungsi untuk mendeteksi jumlah kendaraan yang melewati simpang di Jalan Tentara Pelajar. Berikut adalah dokumentasi denah dari simpangsimpang di Kota Yogyakarta :

Gambar 3.7

Gambar Denah Simpang di Kota Yogyakarta

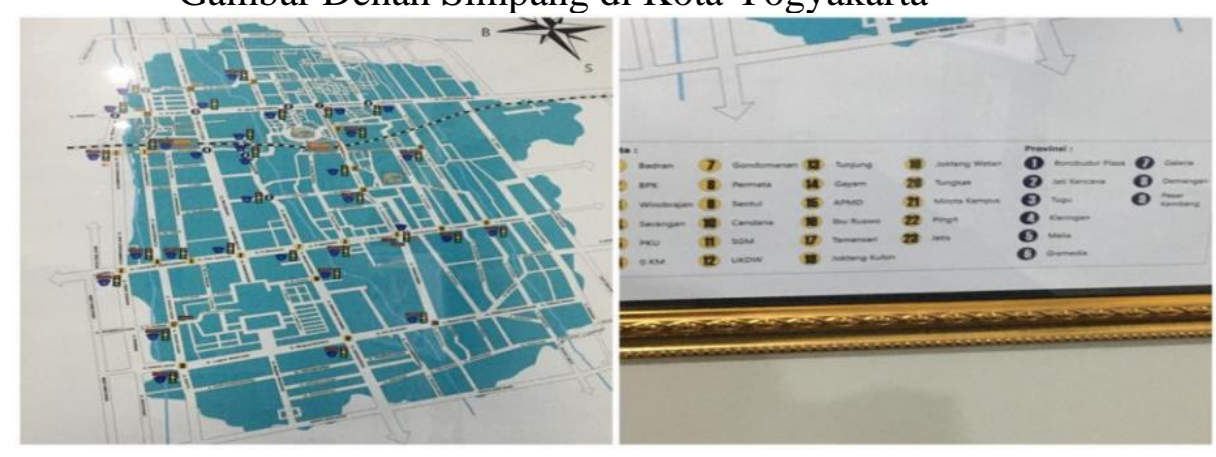

Sumber : Dokumentasi Peneliti 2019

Dinas Perhubungan Kota Yogyakarta dalam upayanya terhadap program pengendalian ketertiban dan kelancaran lalu lintas tidak berjalan sendiri, Dinas Perhubungan menjalin kerjasama dengan Polresta dalam mengawasi dan juga mentertibkan pengendarapengendara yang melewati ruas jalan yang ada di Kota Yogyakarta termasuk juga Jalan Malioboro dan Tentara Pelajar. Beberapa faktor tindakan dari pengguna jalan Malioboro, misanya sering adanya ojol-ojol yang berhenti ataupun menunggu penumpang di pinggir Jalan Malioboro yang seharusnya sepanjang pinggir Jalan Malioboro tersebut tidak boleh berhenti dan beberapa pengunjung Malioboro yang pada saat menyebrang jalan tidak pada tempatnya.

Gambar 3.8 


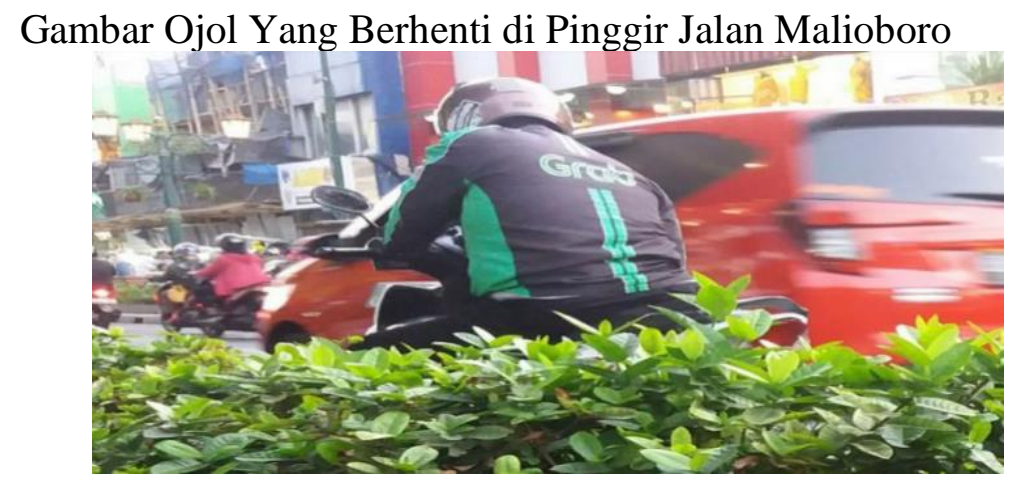

Sumber : Tagar.id

Gambar 3.9

Gambar Pengunjung Malioboro Yang Menyebrang Tidak Pada Tempatnya
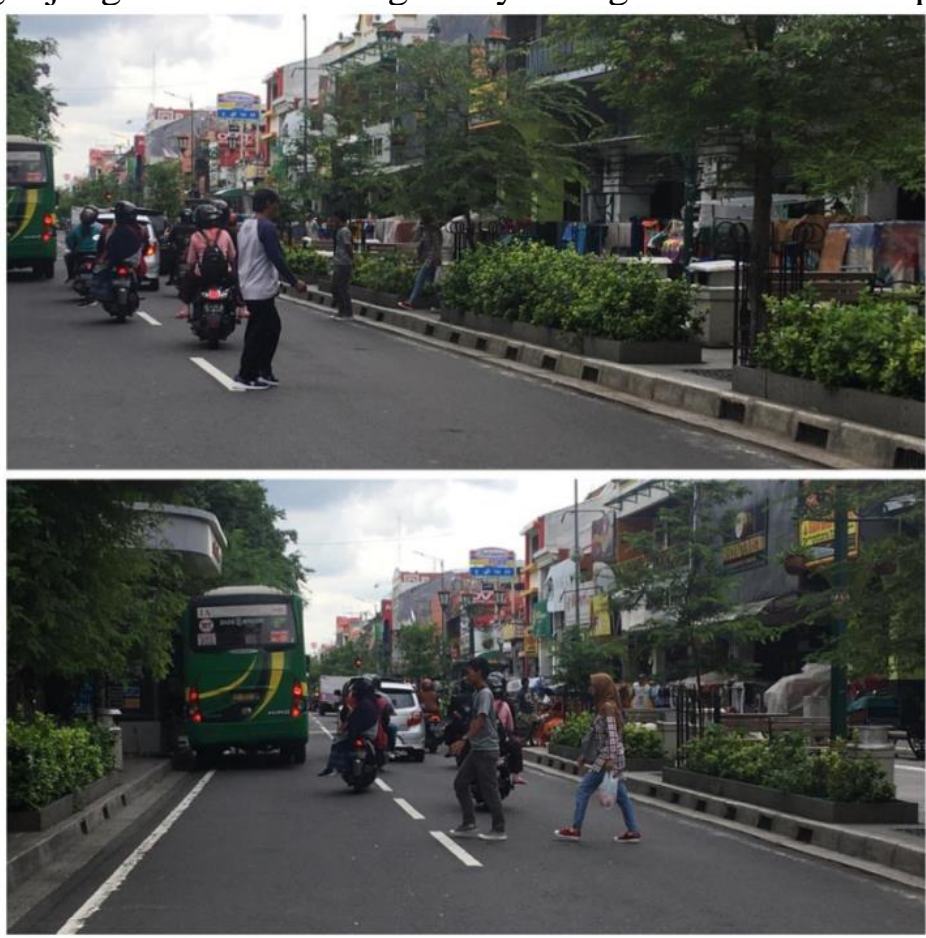

Sumber : Dokumentasi Peneliti 2020

Kemacetan yang terjadi saat ini di Jalan Malioboro terjadi bukan hanya karna banyaknya jumlah kendaraan yang melewati jalan tersebut akan tetapi juga disebabkan oleh beberapa faktor tindakan dari pengguna Jalan Malioboro juga seperti para ojol yang tidak tertib saat berada di Jalan Malioboro, masih adanya masyarakat yang parkir tidak pada tempatnya dan juga pengunjung yang sering kali menyebrang sembarangan dan tidak pada 
zebra cross, hal-hal tersebut jugalah mempenggaruhi kelancaran lalu lintas di Jalan Malioboro itu sendiri. Upaya yang dilakukan oleh Dinas Perhubungan Kota Yogyakarta dengan pendekatan teknologi pengendalian jarak jauhnya yaitu ATCS ini sangat membantu program pengendalian ketertiban dan kelancaran lalu lintas di Jalan Malioboro, pengendalian jarak jauh ini dirasa sudah berjalan baik dan dapat mengurangi kemacetan dan kepadatan yang sering terjadi di Jalan Malioboro itu sendiri. Sedangkan pada Jalan Tentara Pelajar peneliti juga memperoleh data terkait dengan pengendalian ketertiban dan kelancaraan lalu lintasnya dari salah satu pengguna Jalan Tentara Pelajar, berikut kutipan hasil wawancara dengan mbak Indah :

"Menurut yang saya lihat mbak di Jalan Tentara Pelajar ini memang sering padat dan macet yah di jam-jam terntentu apalagi bisa sangat dirasakan pada saat anak-anak pulang sekolah karena sekitar sini kan banyak bangunan sekolah juga jadi banyak yang mengantar jemput, apalagi sekolah-sekolah disini banyak yang berada pas dipinggir jalan mbak otomatis juga penjeputnya parkirnya itu dipinggir jalan juga yah jadinya menganggu pengguna jalan yang lain juga mbak apalagi pada saat padat kendaraan menganggu banget sih mbak, juga kan kita tau sendiri waktu menunggu lampu merah di simpang pinggit ini lama banget yah mba itu juga sih yang buat macet apalagi pada jam-jamnya padat mbak." (Wawancara tanggal 8 Januari 2020)

Mendukung pernyataan diatas, peneliti menemukan hal serupa yaitu di SMP Negeri 12 Yogyakarta yang berada di Jalan Tentara Pelajar dimana orang tua dari siswa disana mengantar anaknya ke sekolah dan menghentikan kendaraannya dipinggir jalan, padahal di sekolah tersebut para pengantar siswa dapat mengantarkan anaknya sampai masuk ke halamam sekolah.

Gambar 3.10

Gambar Pengantar Anak Sekolah Yang Berhenti Di Pinggir Jalan Tentara Pelajar 


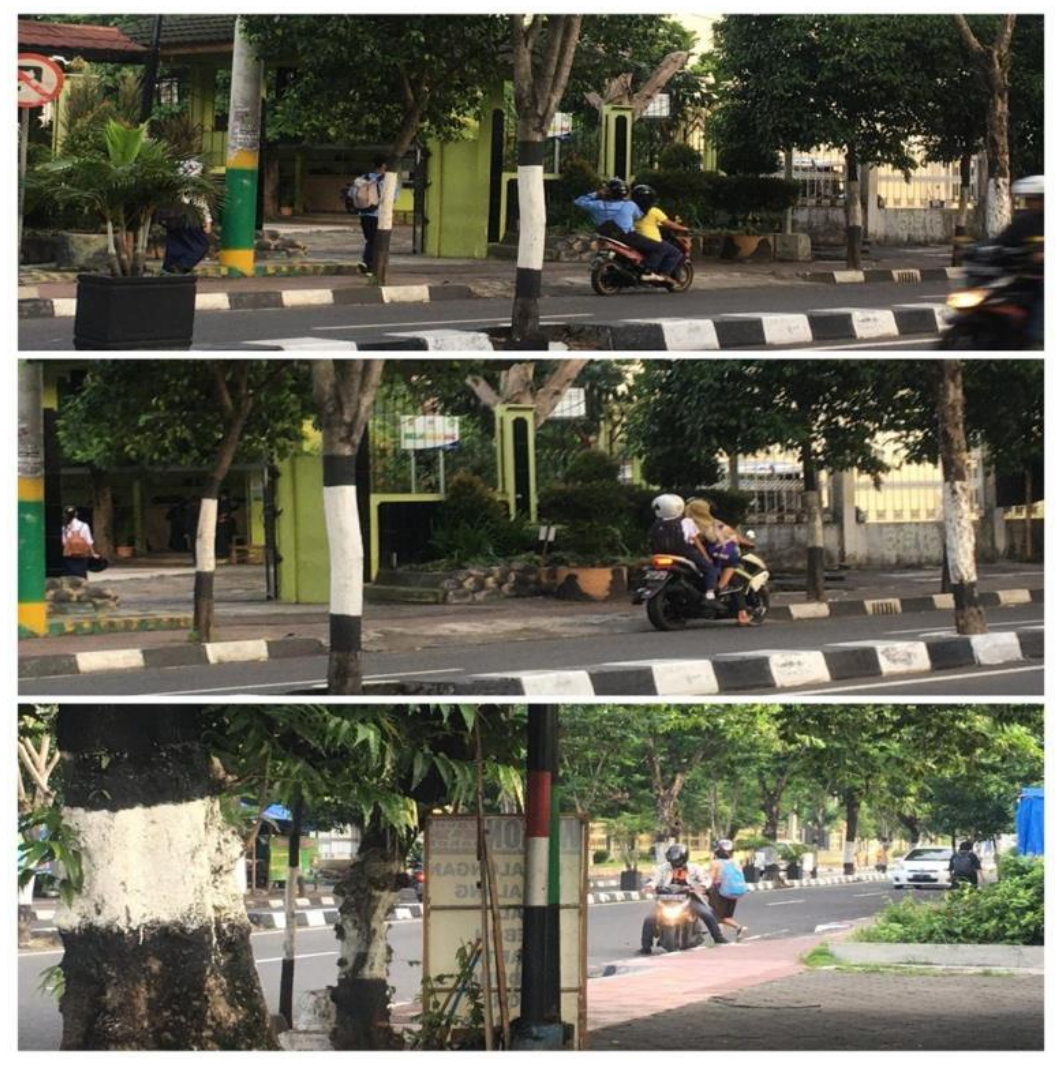

Sumber : Dokumentasi Peneliti 2020

Dilihat dari segi pengendaliannya dari Dinas Perhubungan hanya sebatas lampu merah saja karena di simpang Jalan Tentara Pelajar belum diterapkan teknologi ATCS seperti pada simpang Jalan Malioboro. Sehingga lampu merah pada simpang Jalan Tentara Pelajar ini terbilang cukup lama dan kendaraan yang menunggu menjadi menumpuk ditambah lagi dengan adanya sekolah-sekolah disekitar Jalan Tetara pelajar ini menjadikan banyak orang tua yang mengantar jemput anaknya berhenti maupun parkir di pinggir jalan sehingga membuat pengguna jalan yang lain terganggu.

Program operasionalisasi dan optimalisasi pelenggaraan perparkiran merupakan program yang dilaksanakan oleh Bidang Perparkiran Dinas Perhubungan Kota Yogyakarta, program operasionalisasi dan optimalisasi penyelenggaraan perparkiran ini bertujuan untuk mengatur dan menyediakan area perparkiran untuk para pengendara dan pengguna jalan agar tidak parkir di sembarang tempat seperti bahu jalan dan trotoar yang dapat menganggu kelancaran lalu lintas dan juga kenyamanan pejalan kaki. Seperti yang disampaikan oleh Bapak Lukman Hidayat, SE selaku Kepala Seksi Pembinaan, Pengembangan Perparkiran Dinas Perhubungan Kota Yoyakarta kepada peneliti bahwa pada operasionalisasi itu lebih mengarah pada pendisiplinan penarikan retribusi parkir yang didapatkan sedangkan optimalisasi perparkiran ini mengarah pada bagaimana Dinas Perhubungan mengoptimalkan pendapatan yang ada di 
bidang perparkiran dan juga dari lokasi perparkiran yang sudah ada apa bisa dinaikan lagi pendapatannya dan optimalisasi perparkiran termasuk dalam tingkat pelayanannya di lokasi parkir bisa maksimal juga pemeliharaan lokasi parkir.

Gambar 3.11

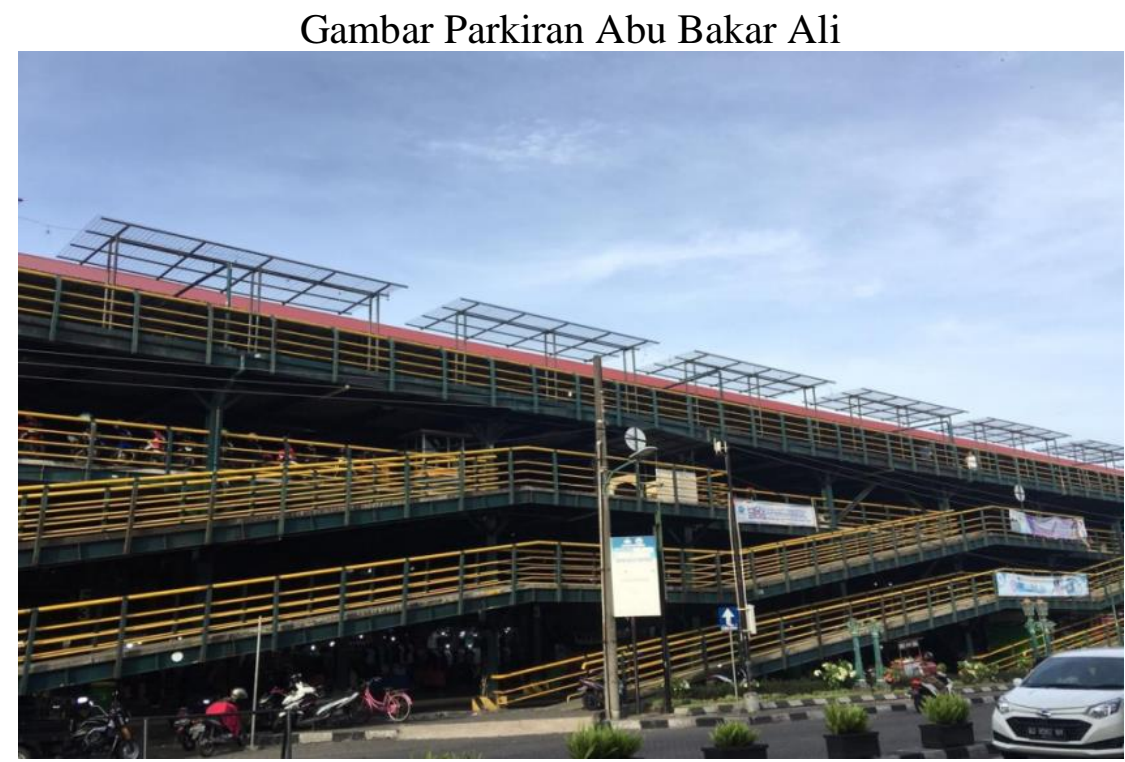

Sumber : Dokumentasi Peneliti 2020

Gambar 3.12

Gambar Parkir Bus Pariwisata di Malioboro

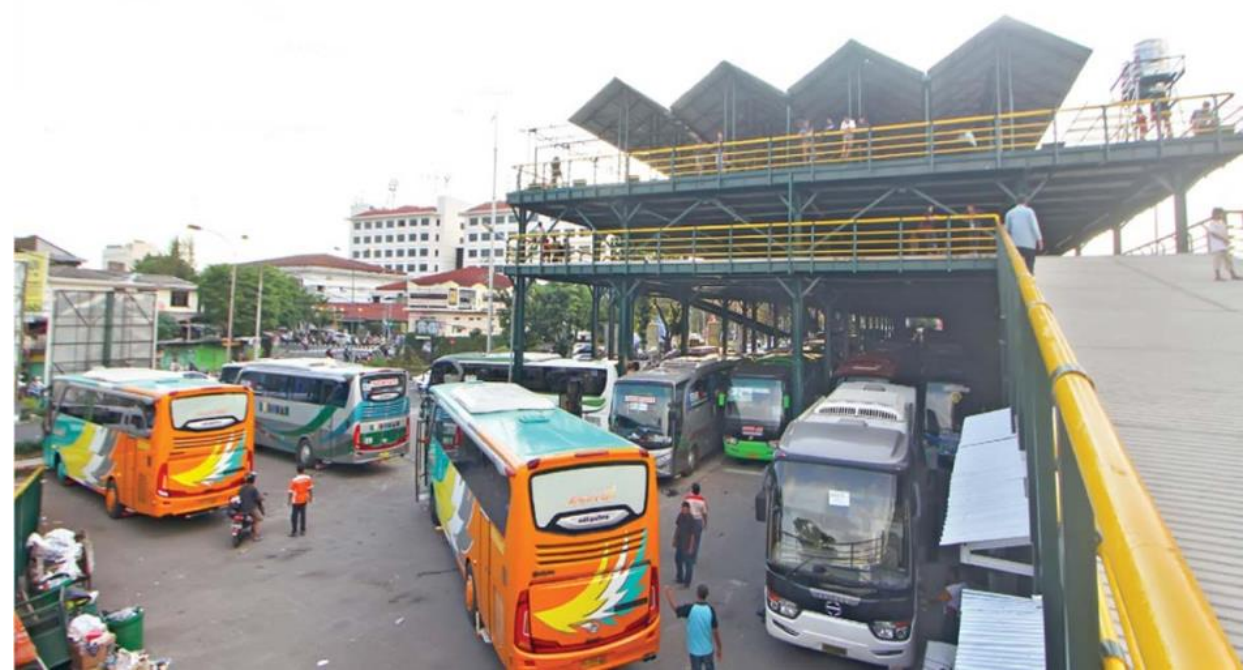

Sumber : Radarjogja.com

Hasil wawancara dengan salah satu pengguna Jalan Malioboro terkait dengan upaya yang telah dilakukan oleh Dinas Perhubungan Kota Yogyakarta yaitu program 
operasionalisasi dan optimalisasi perparkiran yang sudah dilaksankan, berikut kutipan hasil wawancaranya dengan Mas Ridho :

"kalau menurut saya yah pengalokasian parkir di abu bakar ali itu sudah baik tapi jaraknya untuk ke Malioboro cukup jauh, jadi masih banyak yang memilih parkir di dekat dengan tujuan ataupun toko yang dituju. Tapi alokasi parkir disana sudah sangat baik untuk menggurangi kemacetan di Jalan Malioboro juga meningkatkan peminat pengunjung untuk berjalan kaki. Parkir abu bakar ali untuk motor dan bus pariwisata." (Wawancara tanggal 5 Januari 2020)

Kebijakan yang telah dilakukan oleh Dinas Perhubungan Kota Yogyakarta dalam proogram operasionalisasi dan optimalisasi perparkiran seperti pengalokasian parkir motor dan bus pariwisata di parkiran abu bakar ali dan juga di biskalan ramai mall untuk parkir motor dan juga mobil ini sudah cukup baik dan membantu mengurangi kemacetan dan kepadatan lalu lintas di Jalan Malioboro. Akan tetapi masih harus ada peningkatan-peningkatan dari upaya yang telah dilakukan oleh Dinas Perhubungan terkait dengan perparkiran. Karena Jalan Malioboro ini tidak pernah sepi penggunjung dari dalam maupun luar kota sehingga sangat dibutuhkannya lahan-lahan parkir yang dibangun di sepanjang Jalan Malioboro agar para penggunjung dapat dengan mudah mengaksesnya tanpa harus memutar arah. Dilihat dari hasil wawancara peneliti dengan penguguna Jalan Malioboro yang lain banyak dari mereka yang tidak memilih parkir di Abu Bakar Ali dengan alasan yang hampir sama yaitu karena lokasi parkir Abu Bakar Ali yang lumayan jauh dari pusat kawasan Malioboro sehingga banyak yang memilih untuk parkir di dalam Jalan Malioboro dan juga karena akses untuk ke parkiran Abu Bakar Ali yang mengharuskan para pengendara motor memutar arah jika dari arah Jalan Mataram maupun dari Jalan Kota Baru.

Gambar 3.13

Gambar Lokasi Lahan Parkir SD Tarakanita di Jalan Tentara Pelajar 


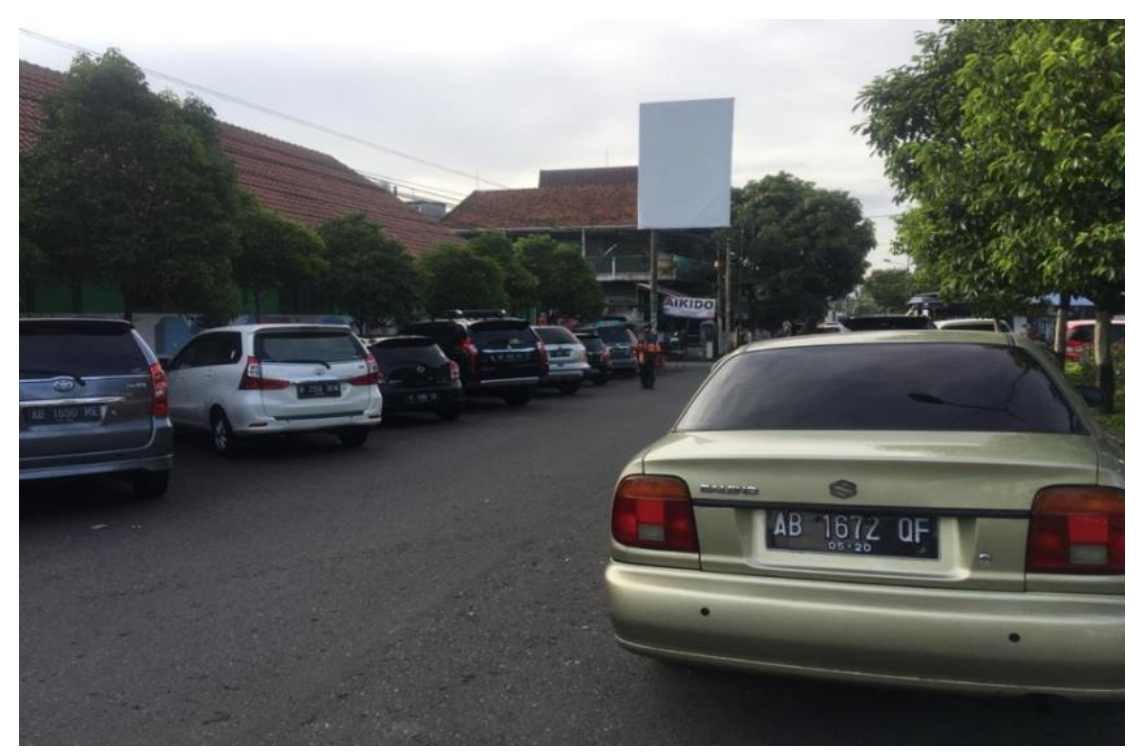

Sumber : Dokumentasi Peneliti 2020

Upaya yang telah dilakukan oleh Dinas Perhubungan Kota Yogyakarta terkait program operasionalisai dan optimalisasi perparkiran di Jalan Tentara Pelajar, yaitu harus terus dilakukannya pembenahan-pembenahan dan juga menambah lahan parkir pada Jalan Tentara Pelajar ini melihat dari fakta dilapangan faktor yang sangat mempengaruhi terjadinya kemacetan dan terganggunya kelancaran lalu lintas di Jalan Tentara Pelajar yaitu masih banyaknya pengendara dan pengguna jalan yang parkir juga berhenti di pinggir jalan, apalagi pada jam-jam padat hal itu sangat menganggu pengguna jalan lain. Bukan hanya dari pihak Dinas saja yang melakukan pembenahan para pengguna Jalan Tentara Pelajar pun harus lebih sadar akan larangan-larangan yang sudah ditetapkan dan penendara dan pengguna jalan harus menanamkan kesadaran diri untuk mentaati peraturan dan menjaga ketertiban saat berkendara agar tindak menrugikan pengendara dan pengguna jalan yang lainnya sebab masalah kemacetan ini bukan hanya beban pemerintah saja masyarakat juga harus ikut mendukung dan ikut membantu agar masalah kemacetan ini dapat diatasi.

Hambatan dan kendala dalam pelaksanaannya dilapangan antara lain perilaku pengendara, pelaku usaha yang mempunyai kepentingan \& perilaku masyarakat. Bapak Lukman Hidayat dalam program operasionalisasi dan optimalisasi perparkiran dilapangan, menjelaskan beberapa faktor penghambat dan kendala yang dihadapi oleh Dinas Perhubungan Kota Yogyakarta, Berikut kutipan hasil wawancaranya :

"Biasanya hambatan dan kendala yang sering kami hadapi dilapangan jadi memang mbak kami masih belum bisa menyediakan lahan parkir yang memadahi lah untuk menampung kendaraan-kendaraan di Jogja ini. Hambatan dan kendala lain juga yang sering kami jumpai dilapangan itu banyak mbak seperti pelaku usaha yang tidak menyediakan lahan parkir untuk menunjang usahanya itu sehingga para penggunjung toko itu parkirnya disembarang tempat yang dapat mengakibatkan terganggunya kelancaran 
lalu lintas. Kita juga merasakan kesulitan untuk membuka lahan-lahan parkir baru mbak karena keterbatasannya lahan kita dalam hal ini biasanya kami melakukan kesepakatan dengan masyarakat yang mempunyai lahan berpotensi untuk dijadaikan lahan parkir itu sehingga dapat menambah lahan-lahan parkir di Kota Jogja ini. Kalau dalam hal sarana dan prasarana menurut saya sudah cukup dan memadahi yah mbak, hambatan yang sekarang tengah kami alami adalah kekurangannya personil kita mbak yah padahal masalah yang harus ditangani disana banyak tentunya kan waktunya jadi lama untuk diproses laporan-laporannya itu." (Wawancara tanggal 30 Desember 2019)

Dari hasil penyampaian informasi dari pihak Dinas Perhubungan Kota Yogyakarta dan juga dari pihak Polantas, dalam pelaksanaan program-programnya untuk mengurangi kemacetan lalu lintas yang ada sudah cukup baik dan selalu berusaha melakukan perbaikanperbaikan demi kenyamanan masyarakat berkendara. Walaupun banyak hambatan dan kendala yang dihadapi dalam proses pelaksanaannya dilapangan tetapi juga mampu untuk mengatasi dan mencari solusi terbaik yang diambil untuk kepentingan bersama. Hambatan dan kendala yang dihadapi dalam mengatasi kemacetan lalu lintas dari aspek sarana prasarananya sudah siap dan memadai untuk diterapkannya program manajement lalu lintas, pengendalian lalu lintas, kelancaran lalu lintas dan pengalokasian paerparkiran ini, akan tetapi terdapat hambatan dan kendala lain dari pelaku usaha yang mempunyai kepentingan dan juga dari perilaku masnyarakatnya yang belum siap akan adanya perubahan dan belum menganggap bahwa manajement lalu lintas seperti jalan menjadi satu arah juga adanya pengalokasian perparkiran itu merupakan suatu solusi untuk mengatasi kemacetan yang terjadi di Kota Yogyakarta ini. Disamping itu juga dari Dinas Perhubungan Kota Yogyakarta sendiri untuk mencapai kesepakatan dengan pelaku usaha dan masyarakat sekitar dengan melakukan sosialisasi dan pertemuan-pertemuan guna mencapai kesepakatan bersama. Jadi Dinas Perhubungan Kota Yogyakarta ini dalam mengatasi hambatan dan kendala yang dialami selalu mencari cara yang terbaik karena kembali lagi yang dihadapi ini adalah perilaku manusia yang bersifat dinamis dan mempunyai kepentingan masing-masing, sehingga dari Dinas Perhubungan Kota Yogyakarta menyelesaikannya dengan melakukan persuasi dengan masyarakat yang bersangkutan hingga sampai menemukan keseimbangan dan kesepakatan bersama.

\section{SIMPULAN DAN SARAN}

\section{SIMPULAN}

Upaya Pemerintah dalam mengatasi kemacetan di Kota Yogyakarta khususnya di Jalan Malioboro dan Tentara Pelajar sudah cukup baik : 
1. Peningkatan pengaturan lau lintas dan angkutan umum sudah dilaksanakan dan diterapkan oleh Dinas Perhubungan Kota Yogyakarta, upaya yang telah dilakukan untuk mengatasi kecematan seperti rekayasa jalan mengalami peningkatan dan pengembangan terhadap manajemennya, tetapi dilapangan masih ada pengendara yang melanggar dan membuat pengguna jalan yang lain terganggu.

2. Pengendalian ketertiban dan kelancaran lalu lintas dari pihak Dinas Perhubungan Kota Yogyakarta telah menggunakan teknologi pengendalian jarak jauh yaitu ATCS (Area Traffic Control System). proses penerapan teknologi ini baru 30 simpang di Kota Yogyakarta yang terpasang.

3. Program operasionalisasi dan optimalisasi Penyelenggaran Perparkiran dari Dinas Perhubungan Kota Yogyakarta, di Jalan Malioboro dan Tentara Pelajar belum terlaksana dengan baik, karena masih banyak pengguna jalan yang menggeluhkan akan kurangnya penyedian lahan parkir.

4. Hambatan dan kendala yang dihadapi dalam mengatasi kemacetan lalu lintas, dari sarana prasarananya sudah siap dan memadai untuk diterapkannya program manajement lalu lintas, pengendalian lalu lintas, kelancaran lalu lintas dan pengalokasian perparkiran, hambatan dan kendala lain seperti masih kurangnya anggaran terkait dengan pengembangan teknoogi ATCS, pelaku usaha yang mempunyai kepentingan dan juga dari perilaku masnyarakat yang belum siap akan adanya perubahan.

\section{SARAN}

1. Perlu segera dilakukannya penerapan teknologi ATCS secara merata pada setiap simpang yang ada di Kota Yogyakarta, pembatasan tehadap kendaraan yang ada seperti di DKI Jakarta, dan perlu ditambah jumlah armada angkutan umum yang dari segi fasilitas dan pelayanannya baik dan memadai.

2. Perlu ada peningkatan sumberdaya manusia dari segi kuantitasnya di bidang perparkiran, sehingga jika adanya laporan dari masyarakat terkait dengan permasalahan yang terjadi dilapangan dapat direspon dengan cepat dan tanggap oleh pihak Dinas.

3. Diadakan sosialisasi kepada masyarakat sekitar Jalan Malioboro dan Tentara Pelajar seperti dibuatkan iklan maupun poster terkait dengan upaya-upaya yang akan dilakukan, agar kedepannya masyarakat mempunyai pemahaman atas upaya apa yang akan dilakukan oleh pemerintah seperti adanya pembukaan lahan parkir baru ataupun rekayasa jalan.

\section{DAFTAR PUSTAKA}

Hikmawati, Fenti. (2017). Metodologi Penelitian. Raja Grafindo Persada. 
Faisal, Sanapiah. (1998). Format Penelitian Sosial. Jakarta. Rajawali Press.

Kamus Besar Bahasa Indonesia ( KBBI ).

Keban, Yeremias T. 2004. Enam Dimensi Strategis Administrasi Publik, Konsep, Teori dan Isu. Yogyakarta: Gava Media.

Maulana, A. (2016). Kinerja Dinas Perhubungan Kota Yogyakarta Dalam Mengatasi Kemacetan Lalu Lintas Tahun 2012-2015.

Natsir, Moh. 1993. Metode Penelitian.Jakarta:Ghalia Indonesia.

Nazir, Muhammad. 2003. Metode Penelitian. Ghalia Indonesia: Jakarta.

Ofyar, Z. (2000). Perencanaan dan Permodelan Transportasi. Bandung. Indonesia.

Rencana Pembangunan Jangka Menegah Daerah (RPJMD) Kota Yogyakarta Tahun 20122016.

RENSTRA Dinas Perhubungan Kota Yogyakarta Tahun 2017-2022

Surakhmad, Wirono. 1989. Pengantar Penelitian Ilmiah. Bandung: Tarsito.

Subarsono. 2009. Analisis Kebijakan Publik. Konsep, Teori dan Aplikasi. Yogyakarta: Pustaka Pelajar.

Sugiyono. 2013. Metodelogi Penelitian Kuantitatif, Kualitatif Dan $R$ \& D. Bandung: Alfabeta.

Sukmadinata. (2011). Metode Penelitian Pendidikan. Penerbit P. T. Remaja Rosdakarya.

Undang-undang Republik Indonesia Nomor 22 Tahun 2009 Tentang Lalu Lintas dan Angkutan Jalan.

Wahab, Solichin Abdul. (2004). Analisis Kebijakan Dari Formulasi Kebijakan, Implementasi Kebijakan Negara, Jakarta: Bumi Aksara. 